\title{
“My lecturer's expressionless face kills me!" An evaluation of learning process of German language class in Indonesia
}

\author{
${ }^{*}$ Primardiana Hermilia Wijayati; ${ }^{2}$ Rofi'ah; ${ }^{3}$ Ahmad Fauzi Mohd Ayub \\ ${ }^{1,2}$ German Department, Faculty of Letters, Universitas Negeri Malang \\ J1. Semarang No.5, Sumbersari, Kota Malang, Jawa Timur 65145, Indonesia \\ ${ }^{3}$ Faculty of Educational Studies, Universiti Putra Malaysia \\ 43400 Serdang, Selangor, Malaysia \\ *Corresponding Author. E-mail: primardiana.hermilia.fs@um.ac.id
}

Submitted: 19 December 2018 | Revised: 20 December 2018 | Accepted: 21 December 2018

\begin{abstract}
This qualitative study aimed at evaluating the circumstances in plenary class that provoke learners' speaking anxiety. To meet the objectives, this study investigated students of German as a Foreign Language (GFL) course who were experiencing speaking anxiety symptoms in the plenary class. The research was a narrative qualitative study, and the data were collected through observation and interview. The result of this study reveals that learners' speaking anxiety occurred in particular circumstances of the plenary class, such as unfamiliar topic, still class, students' unpreparedness for spontaneous speaking, expressionless face of the lecturer, and students' fear of native speaker lecturers.
\end{abstract}

Keywords: speaking anxiety, German as a foreign language (GFL), foreign language anxiety (FLA), sozialform

\section{Introduction}

German is one of the foreign languages learned by several learners in Indonesia, including in Universitas Negeri Malang. Unlike English, German is not an international language that had been learned earlier in the elementary school or even kindergarten. It is also not as familiar as English. In German Department of Universitas Negeri Malang, the students have various backgrounds. Some students have prior knowledge about German from their high schools, some others do not have any knowledge at all and they started to learn German in the university. Students' German language knowledge is standardized through Gemeinsamer Europäischer Referenzrahmen (GER) (2004) or Modern Language Division (2001). According to GER, German skills are divided into three levels i.e. basic level that consists of A1 (breakthrough) and
A2 (Waystage), independent level that consists of B1 (Threshold) and B2 (Vantage), and competent level that consists of C1 (Effective Operational Efficiency) and also C2 (Mastery) (Glaboniat, Müller, Rusch, Schmitz, \& Wertenschlag, 2005). In Universitas Negeri Malang, German was taught with a different level in each semester. Students learned German I (A1) in the first semester, German II (A2) in the second semester, German III (A2B1) in the third semester, German IV (B1) in the fourth semester, and then German B2 (Deutsch auf B2 Niveau) in the fifth semester. The students had to pass the lower level first in order to reach the higher level (Department of German Letters, 2016).

In the class of Deutsch auf B2 Niveau, the students did not learn the whole level. They only learn the beginning or the basis of B2 level. However, students' German language skill at this level should be good, since 
the students already got B1 and B2, which are independent levels. The point is students at this level should be able to communicate in German fluently. However, in fact, according to the preliminary research, the students were quite passive and looked anxious to speak especially when they had to speak in the plenary class or in front of their classmates and teacher. It indicated that they suffered classroom speaking anxiety.

Speaking is one of the language skills that should be acquired by students in a foreign language class. Speaking as a productive activity is very important for them to communicate with each other not only for academic, but also interpersonal context (Lightbown \& Spada, 2006). Speaking is often considered the most difficult language skill because students need to go through a complicated process in order to speak correctly and understandably (McLaren, Madrid, \& Bueno, 2006).

Speaking includes a combination of some cognitive and psychological aspects. In order to achieve successful speaking, students need to have sufficient language knowledge and good psychological (mental) state. The cognitive aspect consists of bottom-up and top-down processes (Bashir, Azeem, Ashiq, \& Dogar, 2011; Saville-Troike, 2006). The bottom-up process involves language knowledge such as vocabulary, pronunciation and grammatical patterns. Meanwhile, the top-down process involves content knowledge about a topic and cultural knowledge of the spoken language. Furthermore, the psychological aspect or mental state also affects students' speaking skill. One of the psychological aspects that affect speaking skill is anxiety (Ansari, 2015; Muhaisen \& Al-Haq, 2012).

Speaking anxiety in a language class is manifested in some ways. Some researches show that speaking anxiety increases students' monitor use (Dulay, Burt, \& Krashen, 1982; El-Sakka, 2016). Students cannot speak fluently because they are self-conscious. This situation worsens their speaking ability (Shabani et al., 2013; Von Wörde, 2003). They cannot achieve their maximum achievement in speaking. Some researches show the cause of students' speaking anxiety, such as lack of fluency, poor knowledge of vocabulary, unfamil- iar topic, and negative feedback (Awan, Azher, Anwar, \& Naz, 2010; Barahmeh, 2013; Nazir, Bashir, \& Raja, 2014). This phenomenon can be seen in almost every language class, including German language class.

Some researches on speaking anxiety in German language class have revealed some familiar findings. Students can suffer fear by speaking in a German language class. The main causes are, for example, fear of negative feedback, low language proficiency, and shyness (Fischer \& Modena, 2005). That fear by speaking leads to speaking anxiety. This anxiety affects students' language ability and worsened their linguistic mastery because they cannot think clearly under those circumstances (Sevinç \& Backus, 2017). These findings are found in German as a second language class. Because speaking anxiety has a huge effect, it is important to investigate speaking anxiety and its form. This research's context is different from previous researches, namely German as a foreign language (GFL) in Indonesia.

It is familiar to see in German as a foreign language class in Indonesia: the lecturer asks a question to the students and they respond it as if it is in a choir. However, when lecturer asks a student to raise a hand and to speak in front of the class, the student keeps quiet as if the class becomes a 'graveyard'. This is because most of the students are passive and anxious to speak in front of the class (Cansrina, 2015). Such description is a kind of culture in German as a foreign language classes in Indonesia.

Based on the preliminary research, the students' passiveness became a serious problem in the classroom. It also gave negative effects toward their performance. During the class, a few students who spoke actively were always the same persons. Thus, the lecturer had to ask or even force the other students to speak. Otherwise, they would only speak with their classmates when they had to interact with each other in pair work or group work.

The students' passiveness and fear of speaking, as mentioned before, show that there were speaking anxiety symptoms among them. This situation normally happened in the plenary class. Plenary class is an interactive form or Sozialform, which is a term defined 
as a didactic methodology that arranges the interaction pattern between students and teachers and among students which consists of plenary class (Frontalunterricht/pleno), individual work (Einzelarbeit), pair work (Partnerarbeit), and group work (Gruppenarbeit) (Kiper, Meyer, \& Topsch, 2002). Thus, this study focused only on the learners' speaking anxiety in the plenary class.

Classroom speaking anxiety is a kind of unpleasant feeling suffered by foreign language learners as they are asked to speak in the classroom. Speaking anxiety is defined as a feeling of fear, nervous, and lack of selfconfidence during speaking which are associated with visual signs (Horwitz, 2001; Horwitz, Horwitz, \& Cope, 1986; Tseng, 2012; Wilson, 2006; Zhiping \& Paramasivam, 2013). Basic (2011) also states that anxiety is a sort of fear manifested by visual signs. Speaking anxiety is a part of Foreign Language Anxiety (FLA) experienced by foreign language learners (Bashir et al., 2011; Horwitz, 2001; Horwitz et al., 1986). Thus, anxiety in the speaking skill is a problem experienced by most of the students in foreign language classes (Arnaiz \& Guillén, 2012; Basic, 2011; Horwitz, 2001; Horwitz et al., 1986; Marwan, 2007; Tseng, 2012; Wilson, 2006; Zhiping \& Paramasivam, 2013). It is caused by the complexity of speaking skill (Basic, 2011). It becomes a reason why the researchers attempted to conduct deeper studies about speaking anxiety with various focuses and results.

Nowadays, there is a number of speaking anxiety studies in English as a Foreign Language (EFL) classes as well as in German as a Foreign Language (GFL) classes. Tseng (2012) explains that there are some factors that can cause speaking anxiety in English classes, such as parents' and teachers' demands for students to get good grades at school in English, lack of confidence in students' ability to learn English, fear of making mistakes and of getting subsequent punishment or ostracism, i.e. fear of having embarrassing feeling for not being perfect, condition in childhood to believe that English is extremely difficult, and fear of foreigners and their behavior. It all shows that English triggers anxiety because of its role as an inter- national language. However, the cause of speaking anxiety in another foreign language, such as German, should be different.

Zhiping and Paramasivam (2013) attempted to look for the cause of speaking anxiety in an international class in Malaysia where the students are from Nigeria, Iran, and Algeria. Their findings revealed that there are particular factors that provoke speaking anxiety, (e.g. fear of being in public and shyness, fear of negative evaluation, and fear of speaking inaccurately). In addition, students' speaking anxiety level is various. It depends on the student and also their culture. Therefore, the cause of speaking anxiety among students was much related to cultural difference since they came from different countries.

The researches about speaking anxiety in German as a Foreign Language (GFL) class had been done by Fischer and Modena (2005) and Cansrina (2015) who investigated speaking anxiety in Modena University in Italy. The results indicate that motivation has a great deal to the success of students' speaking skill. Students with high motivation as well as selfconfidence in learning German can speak German well. Meanwhile, students who suffer speaking anxiety and are afraid to get negative evaluation have low speaking skill. Gnjidić (2016), in his study, has found that anxiety and fear are the biggest obstacles to learning German for Croatian students. When students have a high anxiety level, they can poorly concentrate in producing and expressing their idea through speaking (Fischer \& Modena, 2005; Inozemtseva, 2017).

A local study by Cansrina (2015) divided the causes of German students' speaking anxiety in German Literature Padjajaran University based on three aspects, i.e. personal, social-didactic, and cultural aspects. The cause of speaking anxiety based on personal aspect is too much thinking about grammar and fear of negative evaluation. Based on social-didactic aspect, students will feel anxious to speak when the topics are unfamiliar. Meanwhile, seen from the cultural aspect, students' feeling of fear was provoked by Indonesian teachers' behavior since elementary school, i.e. the students have to keep silent in the class. 
A bit different to the studies by Fischer and Modena (2005), Cansrina (2015), Gnjidić (2016), and Inozemtseva (2017), this study investigated speaking anxiety in particular circumstances of interaction forms in the classroom. Actually, the interaction form of the classroom consists of plenary class, individual-, pair-, and group work, but this study focused on speaking anxiety that occurs only in the plenary class. According to the authors' teaching experiences and the preliminary research, it can be assumed that the students were more passive and anxious in the plenary class rather than in the individual-, pair-, or group work activities. That is why this study focused only on speaking anxiety in the plenary class.

\section{Method}

This qualitative research aimed to evaluate the learning process of German language class in Indonesia by trying to reveal which circumstances of the plenary class that provoked speaking anxiety of German learners in Universitas Negeri Malang. The respondents in this study were students of Universitas Negeri Malang who had ZiDs or Zertifikat Indonesische Deutschstudierende (certificate of German skill for Indonesians students), and who attended Deutsch auf B2 Niveau (German level B2) class as well as Deutsche Literatur (German Literature) class. Such students were selected because they had sufficient input of German. Ideally, they should be able to communicate in German fluently.

Data of the study were collected through observation and interview. The observation was conducted in Deutsch auf B2 Niveau class and Deutsche Literatur class to observe and to notice the symptoms of learners' speaking anxiety during the plenary class. Deutsch auf B2 Niveau was taught by two Indonesian lecturers, while Deutsche Literatur was taught by a German lecturer. In addition, the interview was conducted to support and confirm the data. This study used participant observation, i.e. passive participation. The researchers were not directly involved in the classroom activity, because they rolled as camera persons who recorded and observed the learning process. The researchers came to the class as researchers who observed and recorded the whole activities of the class by using a video recorder. Through the videos, the data were analyzed using an observation sheet. There were several indicators on the sheet to find students who showed speaking anxiety symptoms.

After conducting the observation, there are eight students who were indicated suffering from speaking anxiety were interviewed. The researchers met the students one by one and interviewed them personally to dig deeper data about their speaking anxiety. There were several questions in the interview sheet, but the questions could develop according to the information from the interviewee. It means that the interview was arranged to expose the interviewees' personal view (Creswell, 2013; Sugiyono, 2012).

In qualitative research, data analysis is a continuous process that needs continuous reflection along the study. The technique used in this study was adapted from Spradley that consist of three kinds of analyses, i.e. domain analysis, taxonomy analysis, and componential analysis (Spradley, 1980; Wijayati, 1995). The data in this study were analyzed by those three techniques as mentioned before.

In domain analysis, there is a term called cultural domain. It is a category of cultural meaning that includes small categories. Domain, as the cultural category, consists of three basic elements, i.e. cover term, included term, and semantic relationship (see Figure 1). The cover term is a term for a cultural domain category, included term is a term for smaller cultural domain category, and the semantic relationship is a term that relates the cover term and the included term (Spradley, 1980, p. 89; Wijayati, 1995, p. 32).

The results of the domain analysis were analyzed through taxonomy analysis. It was almost the same as domain analysis that consists of categories arranged by semantic relationship. The difference was taxonomy analysis focused on the relationship that appears at the cultural domain. Then the data were analyzed through componential analysis. A componential analysis was systematic research for the meaning components related to the structural category. The componential analysis 
DOMAIN

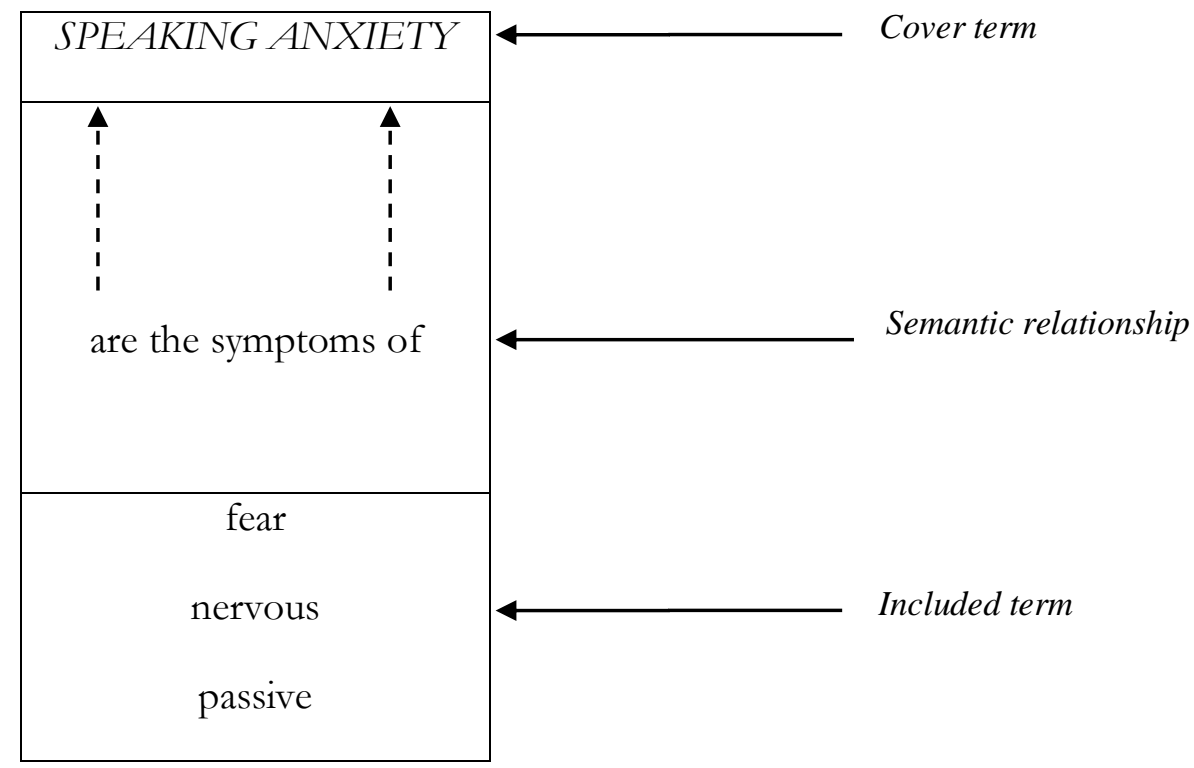

Figure 1. Example of domain analysis

was used to find the meaning which were shown by the research object toward the cultural category (Spradley, 1980; Wijayati, 1995, p. 43).

\section{Findings and Discussion}

Plenary is one of the interaction forms that arrange the interaction pattern between teacher and students in the classroom, in which the teacher stands in front of the class, while the students sit towards the teacher. In the plenary class, the teacher is the master of the class who conducts the learning process. The teacher controls the communication and the learning process of the class (Nuhn, 2000). This kind of interaction form is easy to conduct because it does not need much preparation. Moreover, the teacher could know or even evaluate students' progress in learning a foreign language directly. However, there are particular circumstances of plenary class that provoke learners' speaking anxiety. Based on the study, learners' speaking anxiety occurs during plenary class on particular circumstances, e.g. when the topic is unfamiliar, when the students are unprepared for spontaneous talks, when nobody answers and the class is so still, when the lecturer is expressionless, and when the students are taught by a native speaker.

\section{Unfamiliar Topic}

In the plenary class, the students would like to speak when the topic of the lesson was interesting and familiar to them because they found that it was great and easy. On the contrary, when the topic of the lesson was unfamiliar, they were passive because it was boring and difficult for them to speak. It happened in all classes no matter if they were taught by a German or Indonesian lecturer. Data (1)(13) are the data that show that issue.

(1) When I talk a kind of topic that I used to talk in my daily life, I think my vocabulary is relatively okay, so, it doesn't matter. But when the topic is rather difficult, I feel nervous, Ma'am. (MDCW)

Datum (1) shows that the student was feeling nervous when he had to talk about a difficult topic. Nervousness is one of the speaking anxiety symptoms that occur during speaking (Horwitz, 2001; Horwitz et al., 1986; Lightbown \& Spada, 2006; Spielberger, 1983; Tseng, 2012; Wilson, 2006; Zhiping \& Paramasivam, 2013). Such a case also happened to the following student, as recorded in Datum (2). 
(2) In ZidS class, I got a topic to speak, namely online shop. At that time I really had no idea about that and I said, 'I'm sorry, I have no idea about that, because I never shop online yet... I had no experience about that, so I just can't tell about that topic.' (FNS)

The afore-mentioned description shows that topic played an important role in the classroom interaction. Interesting, easy, and familiar topics could help the students to communicate easily, while difficult and unfamiliar topics provoked learners' speaking anxiety. The students suffered speaking anxiety when the topic was not in their interest. Difficult topics that require higher vocabulary skill provoked the students' fear to speak as well. In addition, unfamiliar topics such as German culture or something that the students never experience by themselves triggered their speaking anxiety. Those research findings support what Cansrina (2015) explains that students have no fear to speak when the topic of the class is interesting.

\section{Unprepared Students for Spontaneous Talk}

The next circumstance that provoked learners' speaking anxiety in the plenary class was when the students were unprepared to talk spontaneously. Based on the observation, the students looked so shy and were smiling when they were being called and being asked to speak. Some of them showed their tension and nervousness. The other students showed repetitive gestures such as scratching their hand and head or touching their face several times, which mean that they were nervous. It can be seen that they suffered speaking anxiety as Basic (2011) says that anxiety is a sort of fear manifested by visual signs.

Based on the interview results, the students were feeling tension when they were suddenly asked to speak. They were afraid because they have no preparation before. It made them speechless, as seen in Datum (3).

(3) When I'm suddenly asked to speak, my mind was blank, and I don't even know what to speak ... First, it is because I don't prepare it well, sometimes the grammar sounds odd either. It is a kind of a mix between tension and confusion. (DNA)

Datum (3) shows that the student experienced mental block or losing an idea because of the sudden call to speak. Mental block indicated that the students suffered anxiety. Horwitz et al. (1986) call it communication apprehension. Communication apprehension is a part of FLA that causes speaking disruption such as stutter, mind blank or losing idea and words, and high intonation or on the contrary. In this study, the students experienced mental block because they were shocked as they were suddenly called to speak. In a long-established habit in Indonesian classes, most of the teachers used to call the students in sequence (based on position or alphabetically). Thus, the students could prepare what to speak while they were waiting for their turns. That is why they were shocked and nervous when they were unprepared for spontaneous talks.

Other data which show that students were feeling the tension and afraid to speak are presented in Data (4) and (5).

(4) When I'm not ready, it is disturbing to be asked to speak. Also it is much better not to ask or freiwillig*. But when I already prepared, it is okay to be asked to speak. (HI) *freiwillig: free willing (to speak)

(5) I feel more afraid when I am asked to speak, because when I don't understand yet, I am not ready, so what do I have to speak? (FWEP)

Data (4) and (5) show that the students were afraid to talk if they are not ready and do not understand the material yet. They were afraid to make mistakes, whether it is in the content or the grammar. Fischer and Modena (2005) and also Zhiping and Paramasivam (2013) state that the cause of speaking anxiety is the fear of making mistakes. In Cansrina (2015) research, the fear of making mistakes as one of the factors that provoke speaking anxiety was not significant, while, in this stu- 
dy, the fear of making mistakes was a big reason that provoked most of the learners' speaking anxiety.

In addition, the students were afraid of negative evaluation, so they were afraid to make mistake when they answered the lecturer's question. It also supports the finding by Fischer and Modena (2005), Zhiping and Paramasivam (2013), and Cansrina (2015) who state that students are afraid of negative evaluation, especially from the lecturer. That is why they suffer speaking anxiety.

\section{Quiet Class}

Based on the observation in Detusche Literatur class, the lecturer asked for the students' opinions about a part of a novel that they have read. Nobody answered. The quieter the class, the worrier were the students. It could be seen in Datum (6).

(6) I don't really understand what that German lecturer wants. I mean, what he wants us to do. Even if I know, but why do my classmates keep silent? The lecturer asked us to do this, but why they say nothing? So I keep silent too. (WDB)

As seen in Datum (6), the students kept silent when there was nobody that has the courage to answer first. They were afraid to reveal their ideas orally (Basic, 2011; Horwitz, 2001; Horwitz et al., 1986; Spielberger, 1983; Tseng, 2012; Wilson, 2006; Zhiping \& Paramasivam, 2013). They also have no interest to speak which indicates that they suffer speaking anxiety (Horwitz et al., 1986).

Based on the observation, the students answered the lecturer's question in a choir. Cansrina (2015) says that they did that because if they were making mistakes, at least they were not alone. They did it together, so they felt safe. However, if no one had the courage to answer, it was better to keep silent. It seemed if somebody talked alone in front of the class and he/she made mistakes, then he/she would become the 'defendant'. It made her/him embarrassed. That circumstance triggered students' shyness, fear, and tension to speak.
Such circumstances created a negative atmosphere in the classroom. The negative atmosphere gave a negative impact to the students. Thus, the negative atmosphere contributed to learners' speaking anxiety. It means that the class needs a positive atmosphere as stated by Cansrina (2015) that a positive atmosphere of the class contributes to learners' speaking activity.

\section{Expressionless Face of the Lecturer}

The next circumstance that provoked learners' speaking anxiety in the classroom was the expressionless face of the lecturer. According to the interview, expressionless face of the lecturers triggered students' tension as presented in Data (7) and (8).

(7) It is even more frightening if the listener's* face was expressionless. If they are nodding, it means ' $\mathrm{O}$, everything is alright' (laugh), but when they show their flat expression, o my, it kills me! What should I do then? (FWEP) *lecturer

(8) Lecturers' expression decides whether I can speak or not. If they ask me to speak with smiling face, I feel, well, still nervous, but not much. But when they are expressionless I'm afraid to speak in front of the class. (FNS)

According to Data (7) and (8), it could be seen that expressionless face of the lecture provoked the learners' speaking anxiety. They were afraid to interpret the lecturer's expression, so they were feeling nervous and afraid to speak. When the lecturer's face was expressionless, the students were frightened by him/ her so that they were afraid to speak freely and they more focused on language accuracy.

The learners' fear caused by the expressionless face of the lecturer appeared because of the learners' own perception. This result did not appear in other relevant speaking anxiety researches. The students were not sure with their own answers. So they guessed the lecturers' expression to know whether their answers were true or false. Thus, they were afraid of making mistakes and afraid of get- 
ting a negative evaluation from the lecturers (Cansrina, 2015; Fischer \& Modena, 2005; Zhiping \& Paramasivam, 2013). Logically, if they were not afraid of negative evaluation, they would not afraid of making mistakes. It means that such perception came from the students themselves.

\section{Native Speaker Lecturer}

In the plenary class of the study, there was a distinction between the class that was conducted by Indonesian and German lecturers. Based on the observation, the students suffered speaking anxiety in particular circumstances, but they were still active enough when they were taught by Indonesian lecturers. Meanwhile, in the class that was conducted by a native speaker, the students were extremely passive. The students were passive and did not want to speak before the lecturer directly asked a student to speak. When the lecturer asked the class, nobody would answer. When the lecturer repeated the question, the students whispered to their classmates and discussed it with them in a whisper. In case they did not understand the question, instead of asking the lecturer directly, they asked their classmates. Some students even avoided eye contact which is one of the speaking anxiety's symptoms (Cansrina, 2015).

According to the interview outcomes, it was because the students had difficulty to understand what the native speaker said. His dialect and accent were a bit different. When Indonesian lecturers spoke, the students could understand their accent, because they had the same mother tongue as the students.

(9) If the language used in the class is full German but the lecturer is Indonesian, they still could express it and their accent is still like Indonesians. But in Deutsche Literatur class that is conducted by a native speaker, it is so confusing, because we have to speak full German and his pronunciation sounds 'extremely German'. Sometimes I do not like to attend the class (laughing). (MD)

(10) Indonesian lecturers may understand when we made grammar mistakes. But native speaker, I'm afraid if they don't understand what we said. I'm afraid so. $(\mathrm{TN})$

According to Data (9) and (10), the students found that Indonesian lecturers could understand them well. Their accent was easy to understand. The students assumed that Indonesian lecturers knew their difficulties in grammar because they had the same mother tongue. In addition, if the students did not understand particular words, Indonesian lecturers could explain it in Indonesian language. That is why the students were feeling glad and safe when they were taught by Indonesian lecturers.

On the contrary, students were nervous when they were taught by a native speaker because they thought that a native speaker could not understand their difficulties and their culture as well as Indonesian lecturers which are evidenced by Datum (11).

(11) When I talked with a native speaker I feel so nervous, because, eee, every time we speak slowly and stuttered, he shows different expressions (confused), but Indonesian lecturers, just like our lecturers, know our behavior well. (TNTR)

In addition, the students thought that a native speaker was the owner of the language they learned. That is why they were being forced by themselves to make the native speaker understood what they said. They thought that the native speaker would notice every grammar mistake they made more than Indonesian (lecturer). For that reason, they had to focus on grammar accuracy that made them more nervous. It could be seen from Data (12 and (13).

(12) Mostly I feel nervous when I talk with German native speaker (German lecturer) because German is his mother tongue. I'm very afraid, whether my grammar is true or false. (WDB)

(13) When there are Germans, I mean, outside of the university, actually I really want to speak with them. But, I'm 
afraid if I make mistake during speaking. They are foreigners who don't understand us well. I'm afraid if I make mistakes and they find it odd or something like that. (FNS)

According to Data (12) and (13), it is found that the class that was conducted by a native speaker provoked difficulty for students. The students felt more nervous and were afraid to interact if the lecturer was a German native speaker because they were afraid to make grammar mistakes. In addition, the data show that the students had a feeling of fear of foreigner. According to the observation, the students avoided the chairs near with the German lecturer. Some chairs in front of the German lecturer were empty at the beginning of the class and the chairs were only for them who came too late as if it was a punishment for them. It shows that the students avoided taking a seat near the native speaker because they did not feel ease and they were afraid of a foreigner.

All of the data mentioned reveal that the students suffered speaking anxiety in the plenary class, when the lecturer was a native speaker. This finding supports the finding of Tseng (2012) that the cause of the learners' speaking anxiety is a fear of foreigner and their behavior. In this study, the students were quite passive and afraid when they were taught by a native speaker, but they did not afraid of his/her behavior. According to the interview, the students found that the German lecturer was nice and humble. However, the students found that the pronunciation and the accent of the German lecturer were quite different and sounded so difficult to understand, unlike the Indonesian lecturers' pronunciation that was easy to understand. The students were also afraid to make grammar mistakes and if the German lecturer did not understand them and their culture as well.

When the students spoke German in front of a German lecturer, the fear of making mistakes intensified because the students assumed that the German lecturer was the owner of the language (German) who would easily notice when the students were making mistakes. That is why they focused on language accuracy. Like what Cansrina (2015) says, that learners' speaking anxiety occurs because they think too much about grammar. That circumstance provoked students not to focus on meaning, but to focus on their fear of making mistakes.

In addition, based on the observation in the Deutsche Literature class, the German lecturer's teaching methods were not quite interesting to the students. They only read the stories in the books. The lecturer asked them the content or the main idea of the stories and their opinion about them. When nobody answered the lecturer's question, the lecturer explained it by himself. On the other day, the German lecturer showed a German poem, explained the difficult vocabulary, and then asked the students to interpret it. Every student kept silent. Then the lecturer explained and interpreted the poem by himself, again. Such methods were boring and too difficult for the students. That is why they had no desire to speak in the classroom.

From all those data, it could be concluded that the students suffered speaking anxiety when the lecturer was a native speaker. They were afraid of making mistakes and getting a negative evaluation from the owner of the language. Besides, they were also afraid of foreigner. In addition, their speaking anxiety increased when the native speaker lecturer's teaching methods were not interesting and too difficult for them.

\section{Conclusion and Suggestions}

Plenary is an interactive form that was often used in the classroom since the teacher could control the communication and the learning process. It was also easy to do (for the teacher/lecturer) and the teacher could know or even evaluate the students' progress in learning a foreign language directly. On the other hand, there were particular circumstances of plenary class that provoked learners' speaking anxiety, such as an unfamiliar topic, unprepared students for spontaneous talks, a still class and nobody who has the courage to talk, the expressionless face of the lecturers, and students' fear of native speaker lecturers. 
To decrease the learners' speaking anxiety, the lecturers need to use particular strategies. The topic spoken in the class should be familiar and interesting so that the learners have the interest to speak. To avoid a silent class, the lecturers should have an asking strategy such as asking with an easy question form, reformulating the question, and giving some examples to the learners. In the end, the lecturers have to appreciate and help the learners by giving good attention with a calm and smiling face to avoid learners' nervousness. It is actually fine to be taught by a native speaker, it would be even more useful, but the native speaker lecturer has to find strategies that could decrease the learners' fear of foreigner, e.g. come closer to the learners' lives in learning context, be humble, and use interesting methods such as games that could enhance the learners' motivation and interest, so that the atmosphere of the class will be fun.

\section{References}

Ansari, M. S. (2015). Speaking anxiety in ESL/EFL classrooms: A holistic approach and practical study. International Journal of Educational Investigations, 2(4), 38-46.

Arnaiz, P., \& Guillén, F. (2012). Foreign language anxiety in a Spanish university setting: Interpersonal differences. Revista de Psicodidáctica, 17(1), 5-26.

Awan, R.-N., Azher, M., Anwar, M. N., \& Naz, A. (2010). An investigation of foreign language classroom anxiety and its relationship with students' achievement. Journal of College Teaching \& Learning, 7(11), 33-40.

Barahmeh, M. (2013). Measuring speaking anxiety among speech communication course students at the Arab American University of Jenin (AAUJ). European Social Sciences Research Journal, 1(3), 229248.

Bashir, M., Azeem, M., Ashiq, \& Dogar, H. (2011). Factor effecting students' English speaking skills. British Journal of Arts and Social Sciences, 2(1), 34-50.
Basic, L. (2011). Speaking anxiety: An obstacle to second language learning? Gävle: University of Gävle.

Cansrina, G. (2015). Ursachen von sprechangst im DaF-Unterricht - Ergebnisse einer untersuchung von Indonesischen studentInnen an der Universitas Padjadjaran. Jurnal Ilmiah Bahasa, Sastra, Dan Budaya Jerman, 2, 168-186.

Creswell, J. W. (2013). Research design: Qualitative, quantitative, and mixed methods approaches (4th ed.). Thousand Oaks, CA: SAGE Publications.

Department of German Letters. (2016). Katalog jurusan Sastra Jerman. Malang: Fakultas Sastra Universitas Negeri Malang.

Dulay, H. C., Burt, M. K., \& Krashen, S. (1982). Language two. New York, NY: Oxford University Press.

El-Sakka, S. M. F. (2016). Self-regulated strategy instruction for developing speaking proficiency and reducing speaking anxiety of Egyptian university students. English Language Teaching, 9(12), 22-33. https://doi.org/ 10.5539/elt.v9n12p22

Fischer, S., \& Modena. (2005). Sprechmotivation und sprechangst im DaFUnterricht. German as A Foreign Language GFL, 3, 31-45.

Gemeinsamer Europäischer Referenzrahmen (GER). (2004). Gemeinsamer europäischer referenzrahmen für sprachen: Kurzinformationen. Langenscheidt: Landesverlag, Linz.

Glaboniat, M., Müller, M., Rusch, P., Schmitz, H., \& Wertenschlag, L. (2005). Profile Deutsch. Langenscheidt: Klett.

Gnjidić, V. (2016). L2 English and L3 German vocabulary learning strategies. Zagreb.

Horwitz, E. (2001). Language anxiety and achievement. Annual Review of Applied Linguistics, 21, 112-126. https://doi. org/10.1017/S0267190501000071

Horwitz, E. K., Horwitz, M. B., \& Cope, J. (1986). Foreign language classroom 
anxiety. The Modern Language Journal, 70(2), 125-132. https://doi.org/ 10.1111/j.1540-4781.1986.tb05256.x

Inozemtseva, N. (2017). Sprechangst internationaler studierender in der fremdsprache Deutsch. Essen: Universität Duisburg-Essen Fakultät für Geisteswissenschaften Institut für Deutsch als Zweit- und Fremdsprache.

Kiper, H., Meyer, H., \& Topsch, W. (2002). Einfübrung in die Schulpädagogik. Oldenburg: Cornelsen.

Lightbown, P. M., \& Spada, N. (2006). How languages are learned (3rd ed.). Oxford: Oxford University.

Marwan, A. (2007). Investigating students' foreign language anxiety. Malaysian Journal of ELT Research, 3(1), 37-55.

McLaren, N., Madrid, D., \& Bueno, A. (2006). TEFL in secondary education. Granada: Universidad de Granada.

Modern Language Division. (2001). Common European framework of reference for language: Learning, teaching, assessment. Strasbourg: Cambridge University Press.

Muhaisen, M. S., \& Al-Haq, F. A.-A. (2012). An investigation of the relationship between anxiety and foreign language learning among 2nd secondary students in Second Amman Directorate of Education. International Journal of Humanities and Social Science, 2(6), 226-240.

Nazir, M., Bashir, S., \& Raja, Z. B. (2014). A study of second language speakinganxiety among ESL intermediate Pakistani learners. International Journal of English and Education, 3(3), 216-229.

Nuhn, H.-E. (2000). Die sozialformen des unterrichts. Pädagogik (Weinheim), 52(2), $10-13$.

Saville-Troike, M. (2006). Introducing second language acquisition. Cambridge: Cambridge University Press.

Sevinç, Y., \& Backus, A. (2017). Anxiety, language use and linguistic competence in an immigrant context: A vicious circle? International Journal of Bilingual Education and Bilingualism, 1-19. https://doi.org/10.1080/13670050.201 7.1306021

Shabani, D. B., Carr, J. E., Pabico, R. S., Sala, A. P., Lam, W. Y., \& Oberg, T. L. (2013). The effects of functional analysis test sessions on subsequent rates of problem behavior in the natural environment. Behavioral Interventions, 28(1), 40-47. https://doi.org/ 10.1002/bin.1352

Spielberger, C. D. (1983). Manual for the statetrait anxiety inventory. Palo Alto, CA: Consulting Psychologists Press.

Spradley, J. P. (1980). Participant observation (1st ed.). New York, NY: Holt, Rinehart and Winston.

Sugiyono. (2012). Metode penelitian pendidikan: Penelitian kuantitatif, kualitatif, dan R\&D. Bandung: Alfabeta.

Tseng, S.-F. (2012). The factors cause language anxiety for ESL/EFL learners in learning speaking. $W H A M P O A-A n$ Interdisciplinary Journal, 63, 75-90.

Von Wörde, R. (2003). Students' perspectives on foreign language anxiety. Inquiry, $8(1), 1-15$.

Wijayati, H. W. (1995). Analisis data penelitian etnografi. Forum Penelitian Kependidikan, 7(1), 32-47.

Wilson, J. T. S. (2006). Anxiety in learning English as a foreign language: Its association with student variables, with overall proficiency, and with performance on an oral test. (Doctoral Thesis). Universidad de Granada, Granada, Spain.

Zhiping, D., \& Paramasivam, S. (2013). Anxiety of speaking English in class among international students in a Malaysian university. International Journal of Education and Research, 1(11), 1-16. 